\title{
Feeding reduction, reproductive failure, and mortality in Mytilus edulis during the 1985 'brown tide' in Narragansett Bay, Rhode Island
}

\author{
Gregory A. Tracey \\ Science Applications International Corporation, Marine Services Branch, US Environmental Protection Agency, \\ Environmental Research Laboratory, Narragansett, Rhode Island 02882, USA
}

\begin{abstract}
During summer 1985, reduced feeding, reproductive failure and massive mortalities were observed in populations of the blue mussel Mytilus edulis during an extremely dense algal bloom (10 cells $\mathrm{ml}^{-1}$ ) in Narragansett Bay, Rhode Island (USA). The dominant alga was an extremely small (1 to $2 \mu \mathrm{m}$ diameter) non-flagellated chrysophycean torm previously unobserved in coastal or offshore waters. Effects of the alga on clearance rates of mussels were tested using natural particulates (NBP) collected from Narragansett Bay during the bloom. Reductions in clearance rate were independent of cell size and extra-cellular exudates of the bloom alga. Experiments repeated with the hard shell clam Mercenaria mercenaria produced similar clearance rate responses. In examining density-dependent effects, NBP concentrations below $2.5 \times 10^{5}$ particles $\mathrm{ml}^{-1}$ allowed normal clearance of a food alga (Isochrysis galbana) and NBP, while significant reductions in the clearance of food algae were observed at NBP concentrations above $5.0 \times 10^{5}$ particles $\mathrm{ml}^{-1}$. In Narragansett Bay, NBP densities increased from $9 \times 10^{5}$ cells ml-1 at seaward stations to above $15 \times 10^{5}$ cells $\mathrm{ml}^{-1}$ in the upper bay. High mortality in indigenous mussels was coincident with peak bloom conditions, varying from 30 to $100 \%$ at stations along the main axis of the bay. In addition, complete reproductive failure of the population was apparent. This effect could not otherwise be explained by environmental conditions of temperature, salinity or dissolved oxygen concentration. It is concluded that starvation stress induced by noxious properties of the bloom alga in combination with seasonal effects (reproductive stage, temperature) was the cause of the demise of $M$. edulis.
\end{abstract}

\section{INTRODUCTION}

Food availability is a critical environmental parameter controlling the metabolic maintenance, growth and reproduction of marine invertebrates (Gabbott 1976, Newell \& Branch 1980). Several factors affecting the quality of food available to suspension feeding bivalves include seston concentration, algal concentration, and the size, shape and ingestibility of food particles (Mohlenberg \& Riisgård 1978, Kiørboe et al. 1980, Bass 1983, Bricelj et al. 1984). In addition, food material must be digestible and of adequate biochemical composition to meet nutritional requirements of the organism (Roman 1983).

Differences in food quality of various phytoplankton species for bivalves have been examined extensively, mainly with application to their cultivation under controlled conditions (Davis \& Guillard 1958, Walne 1970, Ukeles 1980). From laboratory studies, it is clear that there are both beneficial and undesirable phytoplank- ton species (Davis \& Guillard 1958, Davids 1964, Wilson 1981). The documentation of food quality effects on bivalves in the field is relatively rare. The most commonly cited examples of adverse food quality effects are those which occur as a result of 'red tide' blooms, in which toxins associated with certain dinoflagellate species may cause mass mortality in bivalve populations (Helm et al, 1974, Tangen 1977, Boalch 1979). A variety of sub-lethal effects also have been observed, including shell-valve closure, reduced rates of particle clearance, lower metabolic rate, increased mucus production, reduced byssus production and erratic heart rates (Shumway et al. 1985). In regard to observed reduction in clearance rates, one study attributes this effect to toxins within the cell rather than exudates produced by the cell (Widdows et al. 1979).

During summer 1985, a previously undescribed 2.0 $\mu \mathrm{m}$ chrysophycean alga bloomed persistently in Narragansett Bay (Rhode Island, USA) at densities in excess of $1 \times 10^{6}$ cells $\mathrm{ml}^{-1}$. Ultrastructure and morphol- 
ogy of this new picoalga, Aureococcus anophagefferens, are described in detail by Sieburth et al. (1988). The dynamics of the bloom, which peaked on 2 July and shifted to a multi-specific assemblage within $3 \mathrm{wk}$, is fully characterized in Sieburth et al. (1988). During this bloom, casual observations of a reduction in feeding in laboratory-held Mytilus edulis were noted. The purpose of this study was 2-fold: (1) to investigate the apparent relation between reduced feeding in mussels and the Narragansett Bay picoplankton bloom (NBP); (2) to document the magnitude of this effect on natural populations in Narragansett Bay.

\section{MATERIALS AND METHODS}

Mussels Mytilus edulis (45 to $55 \mathrm{~mm}$ long, $0.73 \pm$ $0.25 \mathrm{~g}$ dry tissue weight) and clams Mercenaria mercenaria of similar size were collected from a subtidal population in lower Narragansett Bay $\left(71^{\circ} 24.0^{\prime} \mathrm{W}\right.$, $41^{\circ} 29.4^{\prime} \mathrm{N}$ ) and held in Sargasso sea water overnight prior to experiments.

Feeding experiments were conducted at the US Environmental Protection Agency Environmental Research Laboratory-Narragansett (ERL-N) located on the shore of the west passage of lower Narragansett Bay (Bay Campus, Fig. 1). In feeding experiments,



Fig. 1. Study sites in Narragansett Bay, Rhode Island, USA. (৯) 'Transplant' mussel stations (see 'Materials and Methods'); (w) natural mussel populations mussels and clams were fed various combinations and densities of NBP, a chrysophyte, and an inorganic clay particulate. NBP was collected freshly from the laboratory's water intake system prior to each experiment.

The chrysophyte used was the alga Isochrysis galbana (clone $\mathrm{T}$-iso), a common food source for bivalves (Ewart \& Epifanio 1981). This alga was cultured in ' $\mathrm{f} / 2$ ' nutrient medium (Guillard 1975) and harvested from log-phase cultures prior to feeding experiments. The larger diameter of $I$. galbana cells (5 to $7 \mu \mathrm{m}$ ) allowed the clearance rate of the food alga to be measured independently of NBP within a mixed diet. The inorganic particulate was a commercially available kaolin clay material (Minisil).

Sargasso sea water, adjusted to ambient bay salinity (30 ppt) with deionized water, was used in experiments requiring absence of bloom algae or exudates, as well as to dilute diets to desired concentrations. Bloomconditioned water without particulates was obtained by filtration of raw seawater using $0.45 \mu \mathrm{m}$ pore diameter filters (Nuclepore). Concentration and size-frequency distribution of particles were measured using an electronic particle counter (Coulter Electronics) equipped with a 50 or $100 \mu \mathrm{m}$ aperture and calibrated with known-sized polystyrene spheres. From this information, the volumes of the NBP, clay, and $T$-iso particles were found to be $10.2,17.8$, and $117.8 \mu \mathrm{m}^{3}$, respectively.

Mussels were placed individually into $500 \mathrm{ml}$ rectangular exposure chambers $(12 \times 10 \times 9 \mathrm{~cm})$ and acclimated to the experimental diet for $30 \mathrm{~min}$ prior to clearance rate measurements. Clearance rates $(\mathrm{ml}$ $\mathrm{min}^{-1}$ ) were determined by difference in particle concentration between the beginning $\left(C_{j}\right)$ and end $\left(C_{f}\right)$ of each feeding trial according to the formula of Coughlan (1969)

$$
\text { Clearance rate }=\log _{e}\left(C_{i} / C_{f}\right) \times V / T \text {, }
$$

where $\mathrm{V}=$ chamber volume $\mathrm{T}=$ duration of feeding trial.

In all experiments, clearance rates of 5 mussels were measured during each feeding trial, and the mean $( \pm 1$ standard deviation) response determined for the reporting of results. Three feeding trials (each lasting about 20 min) were conducted in sequence to elucidate any time-dependent interactions within treatments. In examining density-dependent NBP effects (Experiment 4) the results of 2 feeding trials for each treatment were averaged for data reporting. Significant differences between treatments were determined using analysis of variance $(p>F=0.05)$, and the Duncan's multiple range test (Snedecor \& Cochran 1980).

In treatments using food algae, food concentrations were maintained within 1.5 to $10 \times 10^{4}$ cells ml ${ }^{-1}(1.7$ to

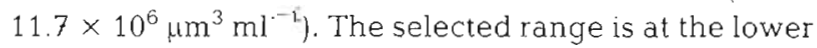
end of cell concentrations $\left(1.7\right.$ to $\left.93 \times 10^{6} \mu \mathrm{m}^{3} \mathrm{ml}^{-1}\right)$ 
where clearance rates of mussels are independent and maximal yet pseudofeces production is minimal (Tenore \& Dunstan 1973, Foster-Smith 1975). The selected range at its upper end approximated the density of NBP at bloom concentrations $\left(1 \times 10^{6}\right.$ cells $\mathrm{ml}^{-1}=10.2 \times 10^{6} \mu \mathrm{m}^{3} \mathrm{ml}^{-1}$ )

Particle size effects. Mussels were fed 2 diets of similar size, one consisting of NBP, the other of clay. An observation of reduced clearance of NBP relative to clay would demonstrate that factors other than particle size were causing a reduction in mussel clearance rates. Initial concentration of particulates for the 3 feeding trials of the clay treatment were (A) $15.8 \pm 1.4$, (B) $10.5 \pm 3.5$, (C) $9.1 \pm 3.7 \times 10^{6} \mu^{3} \mathrm{ml}^{-1}$. For feeding trials of the NBP treatment, initial concentrations were (A) $10.5 \pm 0.6$, (B) $10.2 \pm 0.8$, (C) $9.9 \pm 0.9 \times 10^{6} \mu \mathrm{m}^{3}$ $\mathrm{ml}^{-1}$.

Dissolved exudate effects. Mussel clearance rates of food algae suspended in particle-free Sargasso sea water (SSW + T-iso) were compared with those of a diet of the food alga suspended in bay water collected during the bloom, but filtered to remove NBP (FNBW + $\mathrm{T}$-iso). Initial food alga concentrations in the 3 feeding trials of the SSW + T-iso treatment were (A) $6.1 \pm 1.2$, (B) $4.6 \pm 2.0$, (C) $4.8 \pm 2.5 \times 10^{6} \mu^{3} \mathrm{ml}^{-1}$. In the NBW $+\mathrm{T}$-iso treatment, initial food alga concentrations were (A) $6.4 \pm 0.8$, (B) $8.3 \pm 2.4$, (C) $9.3 \pm 3.7 \times 10^{6} \mu \mathrm{m}^{3}$ $\mathrm{ml}^{-1}$.

Two additional diets - NBP alone (NBP) and NBP with addition of food algae (NBP + T-iso) - were tested to confirm clearance rate reduction effects of NBP in samples of unfiltered bay water. In the NBP + T-iso treatment, initial food alga concentrations were (A) 7.3 \pm 0.7 , (B) $11.7 \pm 1.3$, (C) $9.5 \pm 2.1 \times 10^{6} \mu \mathrm{m}^{3} \mathrm{ml}^{-1}$. In the NBP treatment, initial concentrations were (A) 9.3 \pm 0.1 , (B) $9.1 \pm 0.7$, (C) $8.9 \pm 0.9 \times 10^{6} \mathrm{um}^{3} \mathrm{ml}^{-1}$.

Species-specific effects. Clearance rates of $\mathrm{Mer}$ cenaria mercenaria in response to similar NBP diets were measured for comparison with mussels. $M$. mercenaria was selected for testing because of its role as a dominant and commercially important species in Narragansett Bay (Pratt 1953). Treatments tested were (1) NBP alone (NBP), (2) NBP mixed with food algae (NBP + T-iso), (3) food algae in particle-free Sargasso sea water ( $\mathrm{SSW}+\mathrm{T}$-iso). In the first treatment, initial NBP concentrations for the 3 feeding trials were (A) $10.9 \pm 0.8$, (B) $9.6 \pm 1.2$, (C) $7.8 \pm 0.8 \times 10^{6} \mu^{3} \mathrm{ml}^{-1}$. In the second treatment (NBP $+\mathrm{T}$-iso), initial food alga concentrations were (A) $9.7 \pm 0.7$, (B) $6.2 \pm 2.1$, (C) 3.7 $\pm 1.9 \times 10^{6} \mathrm{um}^{3} \mathrm{ml}^{-1}$. In the third treatment (SSW $+\mathrm{T}$ iso), initial food alga concentrations were (A) $7.8 \pm 0.2$,

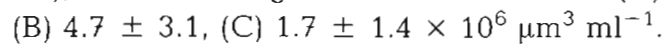

Density-dependent effects. Mussel clearance rates at different dietary concentrations of NBP were measured to determine whether a critical concentration existed above which feeding was reduced. Two types of diets were tested: (1) a series of concentrations, of NBP alone; (2) similar NBP densities added to a diet of food algae (NBP $+T$-iso). Mean concentration of food algae in these experiments was $7.2 \pm 1.2 \times 10^{6} \mu^{3} \mathrm{ml}^{-1}$.

Field studies. The impact of the bloom on indigenous mussels was assessed at 7 stations along the main axis of Narragansett Bay (Fig. 1). Three stations were sites of natural mussel beds (Stations 3, 6 and 7); the others were sites of transplanted mussels (Phelps \& Galloway 1980, Phelps et al. 1987).

Mortality within indigenous mussel beds was determined from 5 samples collected by either SCUBA diver or mussel dredge. Mortality was calculated as the ratio of live mussels to the total of live and moribund animals. Moribund individuals were discriminated from refractory shell material by the presence of intact shells with some tissue remaining. Mortality within transplanted mussels was determined as the percent living of the initial numbers per cage.

Additional environmental variables were monitored in surface $(0.5 \mathrm{~m})$ and bottom $(1.0 \mathrm{~m}$ above bottom) waters of Stations 1, 3, 5, and 7 during the bloom. Temperature and salinity were measured with an inductive salinometer. Whole water samples were collected with a 21 Niskin bottle. Samples for the determination of seston concentration were filtered immediately through pre-tared $0.2 \mu \mathrm{m}$ filters and frozen. Subsequently, the filter was rinsed with isotonic $(2.4 \%)$ ammonium formate to remove salts and dried for $24 \mathrm{~h}$ at $60^{\circ} \mathrm{C}$. Dissolved oxygen samples were fixed in $300 \mathrm{ml}$ glass bottles and the oxygen concentration determined by titration using the Winkler method (Strickland \& Parsons 1972). Particle concentrations in whole water samples were measured by electronic particle counter with a $50 \mu \mathrm{m}$ aperture (Coulter Electronics, Model TAII). The bloom's regional extent was determined by aerial surveys conducted in conjunction with the RI Department of Environmental Management.

\section{RESULTS}

\section{Particle size effects}

Mussel clearance of NBP and clay diets was used to test for effects independent of particle size. The 2 particle types had a similar size-frequency distribution (Fig. 2A), as most particles of both types were 2 to $2.5 \mu \mathrm{m}$ in diameter. Clearance rate responses replicated well for the 3 feeding trials within each treatment (Fig. 2B). In the comparison between treatments, however, mussel clearance rates were 10-fold higher on average for the clay treatment than for the NBP treatment. 

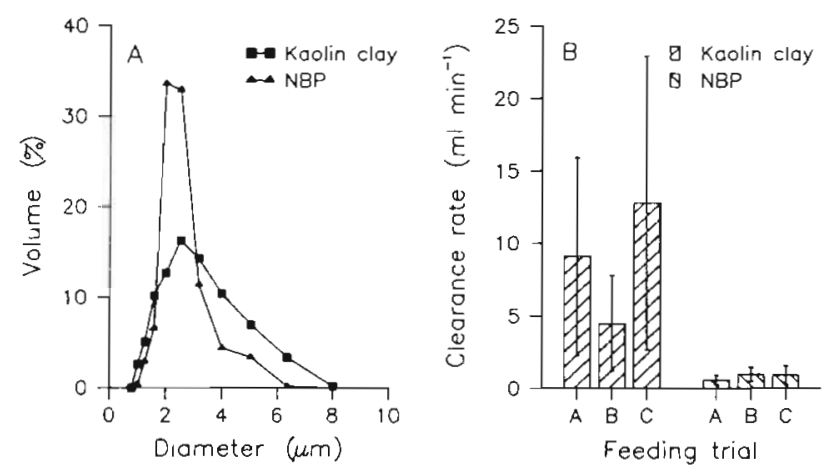

Fig. 2. Mytilus edulis. Tests of particle size effects of bloom particulates (NBP) on mussels. (A) Size-frequency distribution of 2 particle types used in mussel diets. (B) Mussel clearance rates $(X \pm S D)$ of the 2 diets in 3 feeding trials $(A, B, C)$

\section{Dissolved exudate effects}

Mussel clearance rates were used to test for dissolved exudate effects of bloom-conditioned water. Replicate measures of clearance rates were similar within treatments for the different diets (Fig. 3). Differences between treatments of Isochrysis galbana in nonbloom water (SSW $+\mathrm{T}$-iso) and I. galbana in filtered Narragansett Bay water (FNBW + T-iso) were not apparent. In contrast, mussels reduced clearance rates on diets containing NBP, although clearance of food algae in the mixed diet (NBP $+\mathrm{T}$-iso) was greater than that of NBP alone.

\section{Species-specific effects}

The above feeding experiments were repeated with clams for comparison with mussel responses. Clam clearance rates were similar among the 3 feeding trials for each treatment; significant differences in clam clearance rates were found among treatments, however (Fig. 4). Highest clearance rates were observed for the NBP-free food alga diet (SSW $+T$-iso). In comparison, clearance rates of clams on the diet of NBP were reduced significantly. Feeding on food algae in the presence of NBP (NBP + T-iso) also was depressed when compared to that of food algae in particle free Sargasso sea water (SSW + T-iso). Results were similar to those obtained for Mytilus edulis in the second experiment (Fig. 3).

\section{Density-dependent effects}

Mussels were exposed to increasing densities of NBP with and without a food alga present. For a diet of NBP alone, increasing densities up to about $10 \%$ of the

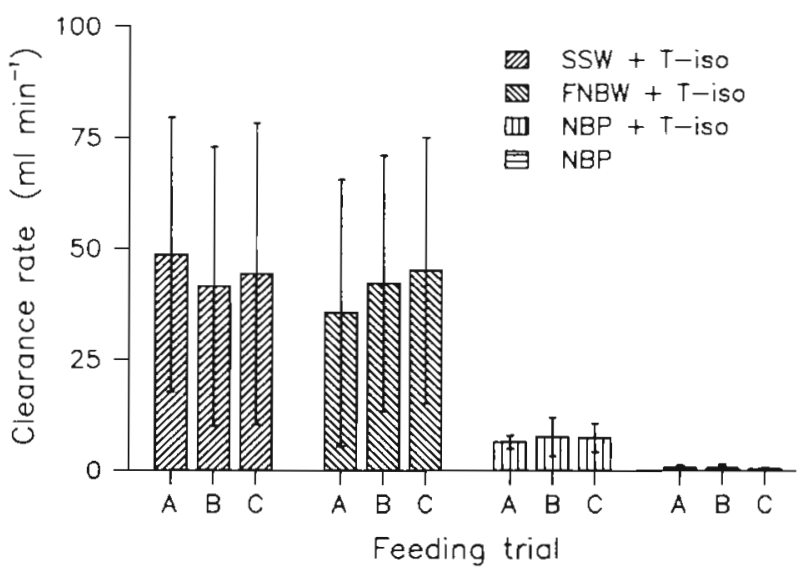

Fig. 3. Mytilus edulis. Tests for effects of extra-cellular exudates from bloom particulates on mussel clearance rates ( $X$ \pm SD). SSW: Sargasso sea 'water, NBP: Narragansett Bay particulates collected during the bloom, FNBW: NBP-conditioned, $0.45 \mu \mathrm{m}$ filtered Narragansett Bay water, T-iso: food algae Isochrysis galbana. (For description of diet formulations see 'Results')

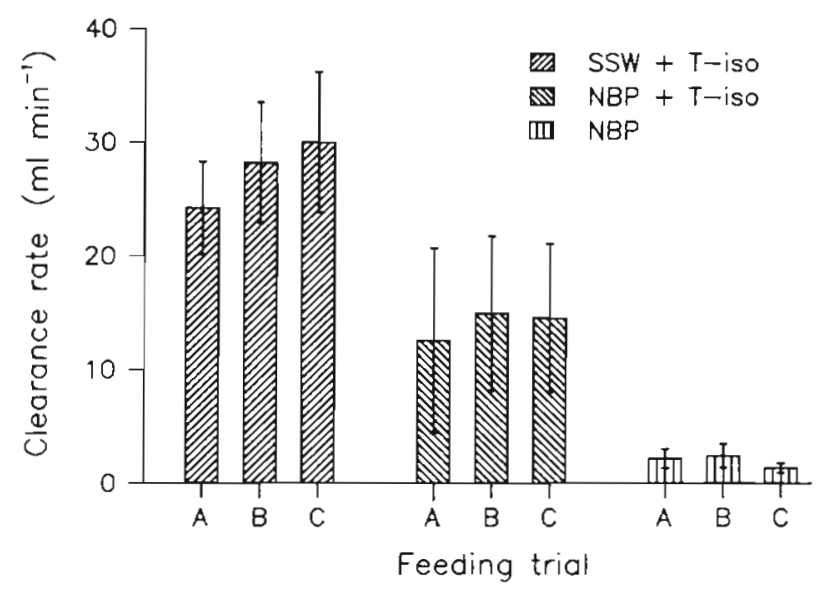

Fig. 4. Mercenaria mercenaria. Tests for effects of bloom particulates on clearance rates of clams $(X \pm S D)$ fed various diets. SSW. Sargasso sea water, NBP: Narragansett Bay particulates collected during the bloom, T-iso: food algae Isochrysis galbana. (For description of diet formulations see 'Results)

bloom $\left(1 \times 10^{5}\right.$ cells $\left.\mathrm{ml}^{-1}\right)$ resulted in increased mussel clearance rates (Fig. 5). However, at higher NBP concentrations a trend of lowered feeding was apparent as clearance rates were reduced significantly at about $70 \%$ of the bloom concentration. Similar effects on mussel clearance rates were also observed in treatments where food algae was present (NBP $+\mathrm{T}$-iso). Concentrations of NBP below $2.5 \times 10^{5}$ cells $\mathrm{ml}^{-1}$ did not appear to affect the clearance of food aigae. Food alga clearance rates decreased markedly, however, when density of NBP was about $50 \%$ of bloom concentration. At bloom concentrations, food alga clearance rates were only $30 \%$ of the rate observed at low NBP densities. 


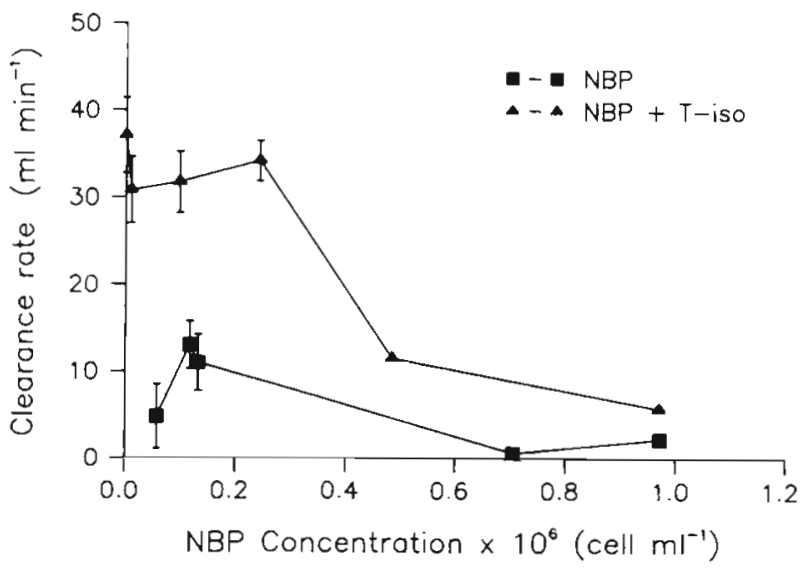

Fig. 5. Mytilus edulis. Tests for density-dependent effects of bloom particulates on mussel clearance rates ( $\pm \mathrm{SD}$ ). NBP. Narragansett Bay particulates collected during the bloom, $\mathrm{NBP}+\mathrm{T}$-iso: NBP in mixture with the food alga Isochrysis galbana

\section{Field observations}

Environmental conditions at selected stations in Narragansett Bay were monitored during the bloom. Temperature declined slightly with greater proximity to offshore waters with the exception of Station 7 (Fig. 1 , Table 1). This station was relatively shallow (4 m) and near a small tidal river which may have flushed warmer water into the region. Salinity also decreased with proximity to the head of the estuary reflecting the fresh water inflow from the Providence river. Dissolved oxygen (DO) concentrations were similar at all stations with surface waters having higher saturation values ( 87 to $95 \%$ ) than bottom waters (65 to $86 \%$ ). Lowest DO was observed in the bottom waters of the upper-most station (5.1 $\left.\mathrm{mgl}^{-1}\right)$.

Concentrations of NBP were in excess of $1 \times 10^{6}$ cells $\mathrm{ml}^{-1}$ at almost all stations, and tended to be higher in the mid-bay region and in surface waters (Table 1). Total suspended matter concentration measured at Station 5 was $5.8 \pm 0.8 \mathrm{mgl}^{-1}$. From aerial surveys conducted during the bloom, the 'brown tide' was visible as a dark brown discoloration of seawater. The bloom was found throughout Narragansett Bay as well as into the south coastal regions of Rhode Island. Plankton samples taken from waters off the University of Rhode Island Narragansett Bay campus (Fig. 1) and examined by transmission electron microscopy revealed that Aureococcus anophagefferens accounted for greater than $95 \%$ of the total algal population (Sieburth et al. 1988).

Inspection of mussels in mid-July revealed high mortalities in both indigenous and transplanted mussels (Table 2). Mortality of indigenous mussels ranged from 30 to $100 \%$. The onset of mortality appeared to occur rapidly as the inspection of these populations $3 \mathrm{wk}$ previously revealed no signs of significant mortality. Samples collected $2 \mathrm{wk}$ later revealed complete mortality in the northernmost population, while few individuals survived at Station 5.

Data from transplanted mussels during summers of 1984 and 1985 indicated a 2-fold increase in mortality during the pico-algal bloom of 1985 (Table 2). While mortality in transplanted mussels during 1984 was 30 to $60 \%$, this effect on indigenous populations is normally offset by recruitment (Katz unpubl.). During the bloom year, however, recruitment was virtually non-existent, as evidenced by an absence of larval settlement on the buoys used for mussel deployments. This condition persisted until the fall of 1986, when some settlement was observed.

\section{DISCUSSION}

Pico-sized particles are a normal complement within the plankton and may often occur up to densities of $1 \times 10^{5}$ cell $\mathrm{ml}^{-1}$ (Sieburth et al. 1978, Johnson \& Sieburth 1982, Davis et al. 1985). Thus, the presence of picoplankton in a bivalve's diet would not be anticipated to disrupt their nutrition. For example, Wright et al. (1982) found that Mytilus edulis cleared phytoplankton from a natural algal and bacterioplankton suspension at rates equivalent to those observed in the laboratory using only phytoplankton in the diet. In Narragansett Bay during summer 1985, however, onset

Table 1. Summary of physical and biological parameters in Narragansett Bay surface and bottom waters during peak bloom conditions (18 July 1985). (For station locations see Fig. 1)

\begin{tabular}{|c|c|c|c|c|c|c|c|c|}
\hline \multirow[t]{2}{*}{ Station } & \multicolumn{2}{|c|}{ Temperature $\left({ }^{\circ} \mathrm{C}\right)$} & \multicolumn{2}{|c|}{ Salinity $(\%)$} & \multicolumn{2}{|c|}{$\mathrm{O}_{2}\left(\mathrm{mg} \mathrm{l}^{-1}\right)$} & \multicolumn{2}{|c|}{$\begin{array}{c}\text { NBP concentration } \\
\left(10^{6} \text { cells } \mathrm{ml}^{-1}\right)\end{array}$} \\
\hline & Surface & Bottom & Surface & Bottom & Surface & Bottom & Surface & Bottom \\
\hline 1 & 23.2 & 22.0 & 26.5 & 27.5 & 7.4 & 5.1 & 1.27 & 1.22 \\
\hline 3 & 22.9 & 19.7 & 28.0 & 29.0 & 6.8 & 6.4 & 1.61 & 1.52 \\
\hline 5 & 19.9 & 17.2 & 30.0 & 30.0 & 7.3 & 6.7 & 1.35 & 1.35 \\
\hline 7 & 21.2 & 20.9 & 31.0 & 32.0 & 7.3 & 6.7 & 1.00 & 0.87 \\
\hline
\end{tabular}


Table 2. Mytilus edulis. Mortality ( $\mathrm{X} \pm \mathrm{SD}$ ) in various locations in Narragansett Bay. For station locations see Fig. 1 Mortality estimates in natural populations indicate mortality occurring during the NBP bloom; transplant mortality data include entire period of June through September for each year

\begin{tabular}{|llrr|}
\hline Station & $\begin{array}{c}\text { Population } \\
\text { type }\end{array}$ & \multicolumn{2}{c|}{ Mortality (\%) } \\
& & 1984 & 1985 \\
\hline 2 & Transplant & $64.3 \pm 5.5$ & $98.9 \pm 1.1$ \\
3 & Natural & & $85.6 \pm 5.8$ \\
4 & Transplant & $31.6 \pm 2.9$ & $61.5 \pm 2.6$ \\
5 & Transplant & $32.6 \pm 5.5$ & $65.5 \pm 3.2$ \\
6 & Natural & & $31.4 \pm 7.2$ \\
7 & Natural & & $100.0 \pm 0.0$ \\
\hline
\end{tabular}

of a picoplankton bloom was associated at first with a reduction in feeding by mussels held within laboratory holding tanks and later with massive mortalities in indigenous populations.

In this study, experiments were conducted to test 4 possible hypotheses as to the cause of mussel feeding reduction during NBP bloom. The first experiment addressed the hypothesis that feeding reduction effects of NBP were independent of particle size. Size-independent effects were confirmed when a depression in mussel clearance rates on an NBP diet was observed relative to a clay diet of similar particle diameter and concentration. Observed rates of Isochrysis galbana

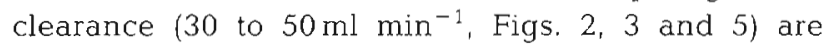
typical for mussels, given their size, algal concentration and temperature (Tenore \& Dunstan 1973, FosterSmith 1975). The lower rates of clay particle clearance (5 to $12 \mathrm{ml} \mathrm{min}{ }^{-1}$, Fig. 1) relative to I. galbana are attributed to the reduction in retention efficiency which occurs for particles smaller than $4 \mu \mathrm{m}$ diameter (Jørgensen 1949, Vahl 1972, Jørgensen 1975, Mohlenberg \& Riisgård 1978, Silvester \& Sleigh 1984). For $2 \mu \mathrm{m}$ diameter particles, the filtration apparatus is about 20 to $40 \%$ efficient (Vahl 1972, Silvester \& Sleigh 1984).

The second experiment addressed the hypothesis that extra-cellular exudates of the bloom alga had caused the reduction in mussel feeding. Extra-cellular exudates of several algal species are known to reduce feeding in bivalves and include species of Chlorella, Stichococcus, Prymnesium and Olisthodiscus (Davis \& Guillard 1958, Davids 1964, Wilson 1981). Given such high bloom densities, the release of even small amounts of inhibiting substances by individual cells could have sufficiently conditioned Bay waters to result in a feeding reduction effect. Results, however, indicate that substances dissolved in bloom water had no effect on clearance rates. In contrast, direct exposure to the particulates contained in the same water sample did cause feeding rate reductions.
Considerable differences exist in the feeding ecology of various bivalve species. For example, Mytilus edulis and Mercenaria mercenaria have different feeding strategies for controlling ingestion when fed high ration diets. In $M$. mercenaria, ingestion is controlled by reducing clearance rate (Bricelj \& Malouf 1984), whereas $M$. edulis maintains clearance rate but increases pseudofeces production (Foster-Smith 1975). Thus, a third experiment addressed the hypothesis that mussels were especially sensitive to NBP exposure because of factors related to the feeding ecology of this particular species, and consequently, other bivalve filter feeders may not have been similarly affected.

In comparing the responses of mussels and clams to diets with and without the presence of NBP, the presence of NBP caused a similar reduction in feeding of both species. The removal of NBP was minimal, while the observed clearance of the food algae without the presence of NBP was comparable to that observed in other uni-algal feeding studies with Mercenaria mercenaria (Bricelj et al. 1984). In addition, the presence of NBP reduced the clearance of food algae by clams as had been found for mussels.

The effects of NBP on clams cannot be explained by high ration. Bricelj \& Malouf (1984) added $5 \mathrm{mgl}^{-1}$ of sediment to a $5 \times 10^{4}$ cells $\mathrm{ml}^{-1}$ diet of the $4 \mu \mathrm{m}$ diameter chrysophycean alga Pseudoisochrysis paradoxa and found no effect on clam clearance rates with the increase in ration. In the present study, NBP represented a similar increase in ration $\left(5.8 \mathrm{mg} \mathrm{l}^{-1}\right)$, and a morphologically similar food alga was fed at equivalent concentrations. These observations of similar feeding reduction in both mussels and clams indicate that the effects of NBP are not species-specific.

The fourth experiment addressed the hypothesis that the effects of NBP were density-dependent. These data were deemed important in predicting the spatial and temporal scales of NBP effects on the nutrition of mussels in Narragansett Bay. The clearance of NBP was affected at about 1 to $7 \times 10^{5}$ particles $\mathrm{ml}^{-1}$ (Fig. 5). Clearance of the food alga was reduced between about 2.5 to $5 \times 10^{5} \mathrm{NBP}$ cells $\mathrm{ml}^{-1}$. No effect of NBP was

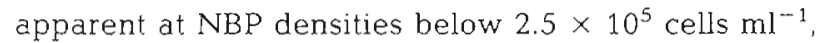
since the rates were comparable to those observed in other mussel feeding studies using only the food alga and mussels of similar size (Tenore \& Dunstan 1973, Foster-Smith 1975, Riisgård \& Randlov 1981). Reductions in clearance observed at NBP concentrations above $5 \times 10^{5}$ cells $\mathrm{ml}^{-1}$ cannot be attributed to satiation effects, since mussel clearance rates would normally remain constant and optimal at cell concentrations 10 -fold greater than those tested in this study (Foster-Smith 1975, Schulte 1975, Winter 1978).

Because laboratory feeding experiments were performed during the height of the bloom using bloom 
particulates, physiological responses observed on mussels in the laboratory were indicative of effects occuring within indigenous populations of Narragansett Bay. Although aerial surveys confirmed the regional extent of a 'brown tide' bloom, picoplankton species composition was determined only in samples taken at the Bay campus (Sieburth et al. 1988). We believe that the composition throughout these waters was similar, and that the dominant species in lower Narragansett Bay, Aureococcus anophagefferens, had played a major role in the observed effects. However, other organisms present in lesser abundance or more dominating in other areas of the Bay could have had an effect on bivalve feeding. Total suspended matter concentrations measured during the bloom were typical for Narragansett Bay (Oviatt \& Nixon 1975), such that adverse effects on mussel feeding due to high seston would not be expected. In addition, environmental conditions were within the tolerance limits of Mytilus edulis (Seed 1976).

Based on the results of this study, it was apparent that the mussel's reproductive activity was synchronized with a period of enhanced primary production. Although such behavior is common and considered advantageous (Newell et al. 1982, Gabbott 1983, Nelson 1987), the observed reproductive failure and mortality in Narragansett Bay mussels was probably exacerbated by the bloom's occurence during active gametogenesis. Given the lack of feeding and seasonally high temperatures the regression and resorption of previously-formed gametes probably occurred (Bayne et al. 1978). This process would subsequently cause reduced viability of eggs and larvae (Bayne et al. 1975, Bayne \& Worral 1980). Further, the bulk of stored energy in the adult would have been committed to continuing reproductive development (Gabbott \& Bayne 1973, Holland \& Spencer 1973, Thompson et al. 1974, Bayne 1975, Sastry 1980), even during complete food deprivation (Bayne et al. 1978). Eventually, the gill and mantle structures required for the intake of food and oxygen degenerate (Pipe 1985). As a result, effects on mussels surviving the NBP bloom may have lasted long after the bloom had subsided below feeding reduction densities.

Mortality induced by NBP was not observed in Narragansett Bay in 1986, but apparently did occur in embayments on Long lsland to such an extent that serious ecological and economic damage in the shellfisheries was reported (Pollack 1985, Knudson 1986, Bricelj et al. 1987). Impacts of the NBP bloom in Narragansett Bay continue, partly because of reproductive failure of mussels during the bloom summer, but primarily because the massive mortalities caused a loss of spawning stock which is required for recruitment in subsequent years.
Previous to these recent events, environmental impacts of pico-sized algal blooms were noted in the decline of the oyster fishery in Moriches and Great South Bay on Long Island in the 1950's concurrent with a shift in phytoplankton towards seasonal dominance of Nannochloris atomus and Nannochloropsis salina (Ryther 1954). This historical event would appear closely related, but in that instance, the effects were probably not related to direct feeding inhibition, but to size limitations and the digestibility of these species (Bass 1983, Bricelj et al. 1984).

Effects caused by NBP bear a greater resemblance to those of red tides, where the mortality of fish and shellfish has been attributed to toxins associated with dinoflagellates (Abbott et al. 1975, Widdows et al. 1979). In this study, however, bacterial-sized particles were responsible, and the plant toxins were apparently not released into the water. Thus, release of toxins would have had to occur on contact with gill cilia or in the gut. The possibility of exo-cellular effects was suggested by transmission electron micrographs of Aureococcus anophagefferens, which revealed a polysaccharide-like mucus coating on its cell surface (Sieburth et al. 1988). This material may have clogged the feeding apparatus or contained an irritant or toxicant to which mussels and other filter-feeders are sensitized. This mechanism was suggested by Pieters et al. (1980), who observed reproductive failure of Mytilus edulis during a bloom of Phaeocystis poucheti, an alga which produced copious quantities of a 'glutinous' material.

Although the principal cause for the bloom's occurrence in Narragansett Bay is unclear, one factor contributing to its persistence may have been an inability of major consumers in the environment to remove NBP from suspension. Usually, algal blooms serve as an important food resource and therefore may be controlled by grazing activity of planktonic and/or benthic filter-feeders (Cloern 1982, Officer et al. 1982). In Narragansett Bay, typical summertime phytoplankton blooms consist of flagellates and diatoms in the 4 to $20 \mathrm{um}$ range (Durbin et al. 1974, Karentz \& Smayda 1984). During the NBP bloom, however, composition of the phytoplankton was dominated by a pico-sized alga of poor food quality. As a result, lack of grazing may have allowed the bloom to intensify beyond normal limits, with catastrophic consequences.

Acknowledgements. Contribution No. x128 of the Environmental Protection Agency Environmental Research Laboratory-Narragansett. The author is indebted to his colleagues at the US Environmental Protection Agency, Environmental Research Laboratory/Narragansett, Rhode Island, especially D. Phelps, W. Nelson, C. Katz, J. Prager and K. J. Scott for support of the research and critical review of the manuscript. This research was funded under EPA. Contract No. 68-03-3236 
to Science Applications International Corporation, Allen D Beck, Project Officer The contents of the manuscript do not necessarily reflect views or policies of the US Environmental Protection Agency. Mention of trade names or commercial products toes not constitute endorsement or recommendation for use by the US Environmental Protection Agency.

\section{LITERATURE CITED}

Abbott, B. C., Siger, A., Spiegelstein, M. (1975). Toxins from the blooms of Gynodinium breve In: LoCicero, V R. (ed.) Proceedings of the first international conference on toxic dinoflagellate blooms. Massachusetts Science and Technology Foundation, Wakefield, p. 355-366

Bass, A. E. (1983). Growth of hard clams, Mercenaria mercenaria, feeding on chlorophyte and cyanobacterial picoplankton. M.S. thesis, Marine Sciences Research Center, State University of New York at Stony Brook

Bayne, B. L. (1975). Reproduction in bivalve molluscs under stress. In: Vernberg, J. (ed.) The physiological ecology of estuarine organisms. Univ. S. Carolina Press, Columbia, p. $259-277$

Bayne, B. L., Gabbott, P. A., Widdows, J. (1975). Some effects of stress in the adult on the eggs and larvae of Mytilus edulis L. J. mar. biol. Ass. U.K. 55: 675-689

Bayne, B. L., Holland, D. L., Moore, M. N., Lowe, D. M. Widdows, J. (1978). Further studies on the effects of stress in the adult on the eggs of Mytilus edulis. J. mar. biol. Ass. U.K. 58: 825-841

Bayne, B. L., Worral, C. M. (1980). Growth and production of mussels Mytilus edulis from two populations. Mar. Ecol Prog. Ser, 3: 317-328

Boalch, G. I (1979). The dinoflagellate bloom on the coast of south west England, August-September 1978. J. mar. biol. Ass. U.K. 59: 515-517

Bricelj, V M., Bass, A. E., Lopez, G. R. (1984). Absorption and gut passage time of microalgae in a suspension feeder: an evaluation of the ${ }^{51} \mathrm{Cr}:{ }^{14} \mathrm{C}$ twin tracer technique. Mar. Ecol. Prog. Ser. 17: 57-63

Bricelj, V M., Epp, J., Malouf, R. E. (1987). Intraspecific variation in reproductive and somatic growth cycles of bay scallops Argopecten irradians. Mar. Ecol. Prog. Ser. 36: 123-137

Bricelj, V M., Malouf, R. E. (1984). Influence of algal and suspended sediment concentrations on the feeding physiology of the hard clam Mercenaria mercenaria. Mar. Biol 84: 155-165

Cloern, J. E. (1982). Does the benthos control phytoplankton biomass in South San Francisco Bay? Mar. Ecol. Prog. Ser 9: $191-202$

Coughlan, J. (1969). The estinution of filtering rate from the clearance of suspensions. Mar Biol. 2: 356-358

Davids, C. (1964). The influence of suspensions of microorganisms of different concentrations on the pumping and retention of food by the mussel (Mytilus edulis L.). Neth. J. Sea Res. 2 (2) : 233-249

Davis, P. G., Caron, D. A., Johnson, P. W., Sieburth, J. MCN. (1985). Phototrophic and apochlorotic components of picoplankton and nanoplankton in the North Atlantic: geographic, vertical, seasonal and diel distributions. Mar. Ecol. Prog. Ser. 21. 15-26

Davis, H. C. Guillard, R. R. L. (1958). The relative value of ten gyenera of microorganisms as food for oyster and clam larvae. U.S. Fish Wildlife Serv. Fish. Bull. 58: 293-304

Durbin, E. G., Krawiec, R. W., Smayda, T J (1974). Seasonal studies on the relative importance of different size frac- tions of phytoplankton in Narragansett Bay. Mar. Biol. 32 : $27.1-287$

Ewart, J. W., Epifanio, C. E. (1981). A tropical flagellate food for larval and juvenile oysters, Crassostrea virginica Gmelin. Aquaculture 22: 297-300

Foster-Smith, R. L. (1975). The effect of concentration of suspension on the filtration rates and pseudofecal production for Mytilus edulis L., Cerastoderma edule (L.) and Venerupis pullastra (Montagu). J. exp. mar Biol. Ecol. 17 . $1-22$

Gabbott, P. A. (1976). Energy metabolism. In: Bayne, B. L. (ed.) Marine mussels. Cambridge Univ. Press, Cambridge pp. 293-356

Gabbott, P. A. (1983). Developmental and seasonal metabolic activities in marine molluscs. In: Hochachka, P. W (ed.) The Mollusca, Vol.2, Environmental biochemistry and physiology. Academic Press, London, p. 165-217

Gabbott, P. A., Bayne, B. L. (1973). Biochemical effects of temperature and nutritive stress on Mytilus edulis L. J. mar. biol. Ass. U.K. 53: 269-286

Guillard, R. R. L. (1975). Culture of phytoplankton for feeding marine invertebrates. In: Smith, W. L., Chanley, M. H. (eds.) Culture of marine invertebrate animals. Plenum Press, New York, p. 29-60

Helm, M. M., Hepper, B. T., Spencer, B. E., Walne, P. R. (1974). Lugworm mortalities and a bloom of Gyrodinium aureolum Hulbert in the eastern Irish Sea, Autumn 1971. J mar, biol. Ass. U.K. 54: 857-869

Holland, D. L., Spencer, B. E. (1973). Biochemical changes in fed and starved oysters, Ostrea edulis L. during larval development, metamorphosis and early spat growth. J. mar. biol. Ass. U.K. 53: 287-298

Johnson, P., Sieburth, J. McN. (1982). In situ morphology and occurrence of eucaryatic phototrophs of bacterial size in the picoplankton of estuarine and oceanic waters. J. Phycol. 18: 318-327

Jørgensen, C. B. (1949). The rate of feeding by Mytilus in different kinds of suspension. J. mar. Biol. Ass. U.K. 28: 333-344

Jørgensen, C. B. (1975). On gill function in the mussel, Mytilus edulis L. Ophelia 13: 187-232

Karentz, D., Smayda, T J. (1984). Temperature and seasonal occurrence patterns of 30 dominant phytoplankton species in Narragansett Bay over a 22-year period (1959-1980). Mar. Ecol. Prog. Ser. 18: 277-293

Kiørboe, T., Mohlenberg, F., Nohr, O. (1980). Feeding, particle selection and carbon absorption in Mytilus edulis in different mixtures of algae and resuspended bottom material. Ophelia 19 (2): 193-205

Knudson, T. J (1986). Long Island gambles on a scallop transplant. New York Times 16 September, p. B-01

Mohlenberg, F., Riisgård, H. U. (1978). Efficiency of particle retention in 13 species of suspension feeding bivalves. Ophelia $17 \cdot 239-246$

Nelson, W. G. (1987). The physiological and reproductive ecology of the mussel, Mytilus edulis L. from two locations in Narragansett Bay, Rhode Island. Ph. D. dissertation, Univ. of Rhode Island, Kingston

Newell, R. C., Branch, G. M. (1980). The influence of temperature on the maintenance of energy balance in marine invertebrates. Adv, mar. Biol. 17: 329-396

Newell, R. I. C., Hilbish, T. J., Koehn, R. K., Newell, C. J. (1982). Temporal variation in the reproductive cycle of Mytilus edulis L. (Bivalvia, Mytilidae) from localities on the east coast of the United States. Biol Bull. mar. biol. Lab. Woods Hole 162: 299-310

Officer, C. B., Smayda, T J., Mann, R. (1982). Benthic filter 
feeding: a natural eutrophication control. Mar. Ecol. Prog. Ser. 9: $203-210$

Oviatt, C. A., Nixon, S. W (1975). Sediment resuspension and deposition in Narragansett Bay. Estuar coast. mar. Sci. 3: 201-217

Phelps, D. K., Galloway, W. B. (1980). A report on the coastal environmental assessment stations (CEAS) program. Rapp. P.-v. Reun. Cons int. Explor. Mer 179: 76-81

Phelps, D. K., Katz, C. H., Scott, K. J., Reynolds, B. H. (1987). Coastal monitoring: evaluation of monitoring methods in Narragansett Bay, Long Island Sound and New York Bight, and a general monitoring strategy. In: Boyle, $T$ P. (ed.) New approaches to monitoring aquatic ecosystems, ASTM STP 940, Amer Soc. Test. Mat., Phila., p. 107-124

Pieters, H., Kluytmans, J. H., Zandee, D. I., Cadee, G. C. (1980). Tissue composition and reproduction of Mytilus edulis dependent upon food availability. Neth. J. Sea. Res. 14: $349-361$

Pipe, R. K. (1985). Seasonal cycles in and effects of starvation on egg development in Mytilus edulis. Mar Ecol. Prog. Ser. 24: 121-128

Pollack, S. (1985). Algal invasion deals Long Island scallopers a crushing blow. National Fisherman 66 (8): 2-4

Pratt, D. M. (1953). Abundance and growth of Venus mercenaria and Callocardia morrhuana in relation to the character of bottom sediments. J. mar. Res. 12: 60-74

Risgård, H. U., Randlov, A. (1981). Energy budgets, growth and filtration rates in Mytilus edulis at different algal concentrations. Mar. Biol. 61 227-234

Roman, M. R. (1983). Nitrogenous nutrition of marine invertebrates. In: Carpenter, E. J., Capone, D. G. (eds.) Nitrogen in the marine environment. Academic Press, London, p. $347-384$

Ryther, J. H. (1954). The ecology of phytoplankton blooms in Moriches Bay and Great South Bay, Long Island, New York. Biol. Bull. mar. biol. Lab., Woods Hole 106 (2): 198-209

Sastry, A. N. (1980). Pelecypoda (excluding Ostreidae). In: Giese, A. C., Pearse, J. S. (eds.) Reproduction of marine invertebrates, Vol. 5. Academic Press, New York, p. $113-292$

Schulte, E. H. (1975). Influence of algal concentration and temperature on the filtration rate of Mytilus edulis. Mar Biol. 30: 331-341

Seed, R. (1976). Ecology. In: Bayne, B. L. (ed.) Marine mussels: their ecology and physiology. Cambridge Press, London, p. 13-66

Shumway, S. E., Cucci, T. L., Gainey, L., Yentch, C. M. (1985). A preliminary study of the behavioral and physiological effects of Gonyaulax tamarensis on bivalve molluscs. In: Anderson, D. M., White, A. W., Bader, D. G. (eds.) Toxic dinoflagellates. Elsevier/North Holland, Amsterdam, p. 389-394
Sieburth, J. McN., Johnson, P. W., Hargraves, P. E. (1988). Characterization of Aureococcus anophagefferens Gen. et sp. nov. (Chrysophyceae); the dominant picoplankter during a bloom in Narragansett Bay, Rhode Island, summer 1985. J. Phycol. 24. 416-425

Sieburth, J. McN., Smetacek, V., Lenz, J. (1978). Pelagic ecosystem structure: heterotrophic compartments of the plankton and their relationships to plankton size fractions. Limnol. Oceanogr 23: 1256-63

Silvester, N. R., Sleigh, M. A. (1984). Hydrodynamic aspects of particle capture by Mytilus. J. mar. Biol. Ass. U.K. 64: $859-879$

Snedecor, D. W., Cochran, W G. (1980). Statistical methods. Iowa Univ. Press, Ames

Strickland, J. D. H., Parsons, T. R. (1972), A practical handbook of sea water analysis. Bull. Fish. Res. Bd. Can. 167 : $1-311$

Tangen, K. (1977). Blooms of Gyrodinium aureolum (Dinophyceae) in north European waters, accompanied by mortality in marine organisms. Sarsia 63: 123-133

Tenore, K. R., Dunstan, W M. (1973). Comparison of feeding and biodeposition of three bivalves at different food levels. Mar. Biol. 21, 190-195

Thompson, R. J., Ratcliff, N. A., Bayne, B. L. (1974). Effects of starvation on the structure and function of the digestive gland of the mussel (Mytilus edulis L.). J. mar, biol. Ass. U.K. 54: 699-712

Ukeles, R. (1980). American experience in the mass culture of micro-algae for feeding larvae of the american oyster, Crassostrea virginica. In: Shelef, G. A., Soeder, C. J. (eds.) Algal biomass: production and use. Elsevier Press, New York, p. 287-306

Vahl, O. (1972). Efficiency of particle retention in Mytilus edulis. Ophelia 10: 17-25

Walne, P. R. (1970). Studies of the food value of nineteen genera of algae to juvenile bivalves of the genera Ostrea, Crassostrea, Mercenaria and Mytilus. Fishery Invest., Lond. 2, vol. 26 (5): 1-62

Widdows, J., Moore, M. N., Lowe, D. M., Salkeld, P. M. (1979). Some effects of a dinoflagellate bloom (Gyrodinium aureolum on the mussel, Mytilus edulis. J. mar biol. Ass. U.K. 59: 522-524

Wilson, D. P. (1981). An experimental search for phytoplanktonic algae producing external metabolites which condition natural sea waters. J. mar. Biol. Ass. U.K. 61: 585-607

Winter, J. E. (1978). A review of the knowledge of suspensionfeeding in lamellibranchiate bivalves, with special reference to artificial aquaculture systems. Aquaculture 13: $1-33$

Wright, R. T., Coffin, R. B., Ersing, C. P., Pearson, D. (1982). Field and laboratory measurements of bivalve filtration of natural marine bacterioplankton. Limnol. Oceanogr. 27 (1): 91-98 